Agnieszka Rumik, Iwona Paradowska-Stankiewicz, Jolanta Rudowska, Irena Chrześcijańska

\title{
PERTUSSIS IN POLAND IN 2016*
}

\author{
KRZTUSIEC W POLSCE W 2016 ROKU*
}

National Institute of Public Health - National Institute of Hygiene in Warsaw,

Department of Epidemiology of Infectious Diseases and Surveillance

Narodowy Instytut Zdrowia Publicznego - Państwowy Zakład Higieny w Warszawie,

Zakład Epidemiologii Chorób Zakaźnych i Nadzoru

\begin{abstract}
INTRODUCTION. In Poland, the high incidence of pertussis has been maintained for 10 years - in 2016 it was 17,77 per 100,000 population and it was $38 \%$ more compared to the previous year. The high percentage of pertussis is still present in those who are older, who may be a source of infection for non-immunized or not fully immunized newborns and infants. The most effective prevention strategy remains the implementation of vaccinations in accordance with the current calendar.

OBJECTIVES. The aim of the article is to assess the epidemiological situation of pertussis in Poland in 2016 compared to the situation in previous years, with particular emphasis on the assessment of the status of inoculation of children against pertussis.

MATERIALS AND METHODS. Analysis of the epidemiological situation of pertussis in Poland was carried out on the basis of individual reports of suspected cases of pertussis sent to NIZP-PZH by regional sanitaryepidemiological stations, data from the bulletin "Infectious diseases and poisoning in Poland in 2016"(2) and the bulletin "Protective vaccinations in Poland in 2016"(3).

RESULTS. In 2016, 6828 cases of pertussis were registered. The incidence was 17.77 per 100,000 population and was $38 \%$ higher compared to the previous year (12.89). The highest incidence of pertussis occurred in people aged 10-14 (88.1), and high in children aged 0 and 3 years - 76.7 and 77.0 per 100,000 population. Of the 6828 patients with pertussis, 1640 people were hospitalized (24\% of total). In 2016 , no deaths were reported due to pertussis.

SUMMARY AND CONCLUSIONS. The increase in pertussis observed in 2016 indicates the persistent circulation of bacteria in the environment and still persistent population sensitivity to infection. The only effective strategy to reduce the number of cases remains the use of vaccinations according to the current calendar and recommendations of experts.
\end{abstract}

Key words: pertussis, infectious diseases, epidemiology, Poland, 2016

\section{STRESZCZENIE}

WSTĘP. W Polsce od ponad 10 lat utrzymuje się wysoka zapadalność na krztusiec - w roku 2016 wyniosła 17,77 na 100 tys. ludności i była o 38\% większa w porównaniu z rokiem poprzednim. Nadal wysoki odsetek stanowią zachorowania na krztusiec osób w wieku starszym, które mogą być źródłem zakażenia dla nieuodpornionych lub nie w pełni uodpornionych noworodków i niemowląt. Najskuteczniejszą strategią zapobiegania zachorowaniom pozostaje realizacja szczepień zgodnie z obowiązującym kalendarzem.

CEL PRACY. Celem pracy jest ocena sytuacji epidemiologicznej krztuśca w Polsce w $2016 \mathrm{r}$. w porównaniu z sytuacją w ubiegłych latach, ze szczególnym uwzględnieniem oceny stanu zaszczepienia dzieci przeciw krztuścowi.

MATERIAŁ I METODY. Ocena sytuacji epidemiologicznej krztuśca w Polsce została przeprowadzona na podstawie wyników analizy jednostkowych zgłoszeń podejrzeń/ zachorowań na krztusiec nadsyłanych do NIZP-PZH przez wojewódzkie stacje sanitarno-epidemiologiczne oraz danych z biuletynu „Choroby zakaźne i zatrucia w Polsce w 2016 r.”(2) i biuletynu „Szczepienia ochronne w Polsce w 2016 r.”(3).

*Article was written under the task No.6/EM.1/2017 / Praca została wykonana w ramach zadania nr 6/EM.1/2017

(C) National Institute of Public Health - National Institute of Hygiene / Narodowy Instytut Zdrowia Publicznego - Państwowy Zakład Higieny 
WYNIKI. W 2016 r. zarejestrowano 6828 zachorowań na krztusiec. Zapadalność wynosiła 17,77 na 100 tys. mieszkańców i była o $38 \%$ wyższa w porównaniu z zapadalnością w poprzednim roku $(12,89)$. Najwyższa zapadalność na krztusiec wystąpiła u osób w grupie wieku 10-14 lat $(88,1)$, a wysoka u dzieci w wieku 0 i 3 lata - 76,7 i 77,0 na 100 tys. mieszkańców. Spośród 6828 osób chorych na krztusiec 1640 osób (tj. 24\%) było hospitalizowanych. W 2016 r. nie zgłoszono zgonów z powodu krztuśca.

PODSUMOWANIE I WNIOSKI. Obserwowany w 2016 r. wzrost zachorowań na krztusiec wskazuje na utrwalone krążenie bakterii w środowisku i nadal utrzymującą się wrażliwość populacji na zakażenie. Nadal jedyną skuteczną strategią ograniczenia liczby zachorowań pozostaje stosowanie szczepień wg obowiązującego kalendarza oraz zaleceń ekspertów.

Słowa kluczowe: krztusiec, choroby zakaźne, epidemiologia, Polska, 2016 rok

\section{BACKGROUND}

In Poland, the high incidence of pertussis has been maintained for many years - the five-year median incidence rates for 2005-2009 and 2010-2014 were 5.2 and 5.5 per 100,000 population. 2015 was a year of epidemic intensity, in which there was a significant increase (by 136\%) of incidence up to 12.89 per 100,000 population. In 2016, the increase (by 38\%) of incidence to 17.77 per 100,000 population was maintained. The highest percentage of cases of pertussis is still recorded in the group of patients aged 15 and more, despite the fact that the percentage of incidences in this group shows a downward trend (from $54.2 \%$ in 2012 to $45.8 \%$ in 2016). ) (Tab.I). A high percentage of cases of pertussis in people of older age groups is an important source of infection for non-immunized or not fully immunized newborns and infants who have the most severe clinical course. It should be emphasized that still the most effective strategy for preventing pertussis cases remains the implementation of vaccinations in accordance with the current calendar.

Pertussis is a disease that is subject to mandatory reporting and registration. Serological diagnosis of any suspected of having pertussis disease includes the determination of specific antibodies for pertussis toxin in the IgA and IgG class - this should be a routine diagnostic procedure for clinical needs as well as for epidemiological surveillance.

\section{OBJECTIVES}

The aim of the article is to assess the epidemiological situation of pertussis in Poland in 2016 compared to the situation in previous years, with particular emphasis on the assessment of the status of inoculation of children and adolescents against pertussis.

\section{MATERIAL AND METHODS}

The analysis of the pertussis epidemiological situation in Poland was carried out on the basis of individual suspicions/cases of pertussis sent to NIZP-

\section{WSTĘP}

W Polsce od wielu lat utrzymuje się wysoka zapadalność na krztusiec - pięcioletnie mediany zapadalności za lata 2005-2009 i 2010-2014 wynosily odpowiednio 5,2 i 5,5 na 100 tys. ludności. Rok 2015 był rokiem nasilenia epidemicznego, w którym wystąpił znaczący wzrost (o 136\%) zapadalności do 12,89 na 100 tys. ludności. W roku 2016 utrzymał się wzrost (o 38\%) zapadalności do poziomu 17,77 na 100 tys. ludności. Nadal rejestruje się najwyższy odsetek zachorowań na krztusiec w grupie osób w wieku 15 lat i więcej, pomimo że udział procentowy zachorowań tej grupy wieku wykazuje tendencję spadkową (z 54,2\% w 2012 r. na 45,8\% w 2016 r.) (Tab.I). Wysoki udział procentowy zachorowań na krztusiec osób w starszych grupach wieku stanowi ważne źródło zakażenia dla nieuodpornionych lub nie w pełni uodpornionych noworodków i niemowląt, u których zachorowanie ma najcięższy przebieg kliniczny. Należy podkreślić, że nadal najskuteczniejszą strategią zapobiegania zachorowaniom na krztusiec pozostaje realizacja szczepień zgodnie z obowiązującym kalendarzem.

Krztusiec jest chorobą, która podlega obowiązkowemu zgłaszaniu i rejestracji. Diagnostyka serologiczna każdego podejrzanego o krztusiec zachorowania obejmuje oznaczenie swoistych przeciwciał dla toksyny krztuścowej w klasie IgA i IgG - powinno to stanowić rutynowy sposób postępowania diagnostycznego na potrzeby kliniczne, jak i na potrzeby nadzoru epidemiologicznego.

\section{CEL PRACY}

Celem pracy jest ocena sytuacji epidemiologicznej krztuśca w Polsce w 2016 r. w zestawieniu z sytuacją w ubiegłych latach, ze szczególnym uwzględnieniem oceny stanu zaszczepienia dzieci i młodzieży przeciw krztuścowi.

\section{MATERIAŁ I METODY}

Ocena analizy sytuacji epidemiologicznej krztuśca w Polsce została przeprowadzona na podstawie indywidualnych zgłoszeń podejrzeń /zachorowań na krztusiec 
PZH by Regional Sanitary-Epidemiological stations and data from the bulletin "Infectious diseases and poisoning in Poland in 2016" (2) and "Immunizations in Poland in 2016 "(3) The classification of pertussis cases was made on the basis of definitions ("Definitions of infectious diseases for the purposes of epidemiological surveillance") (4). According to the above definition, clinical criteria are met by every person who has a cough lasting at least two weeks and at least one of three symptoms: coughing attacks, bouts of apnea after coughing or vomiting occurring immediately after coughing or any person with whom the doctor recognized pertussis or attacks of apnea in infants. Laboratory criteria include at least one of three criteria: isolation of Bordetella pertussis from a clinical specimen, detection of Bordetella pertussis nucleic acid in a clinical specimen, detection of a significant increase in specific antibodies against Bordetella pertussis. Epidemiological criteria are met when there is an epidemiological link involving the transmission of infection from person to person. Based on clinical, laboratory and epidemiological criteria, the following case classification has been established:

A. A possible case - every person who meets clinical criteria

B. Probable case - each person meeting clinical and epidemiological criteria

C. Confirmed case - every person who meets clinical and laboratory criteria.

\section{RESULTS}

In 2016, 6828 cases of pertussis were registered, ie by $38 \%$ more than in the previous year. The incidence in 2016 in Poland was 17.77 per 100,000 population and was higher compared to the previous year (12.9) (Tab.I). nadsyłanych do NIZP-PZH przez wojewódzkie stacje sanitarno-epidemiologiczne oraz danych $\mathrm{z}$ biuletynu rocznego „Choroby zakaźne i zatrucia w Polsce w 2016 r.”(2) oraz „Szczepienia ochronne w Polsce w 2016 r.”(3) Klasyfikacji przypadków zachorowań na krztusiec dokonano na podstawie definicji (,Definicje przypadków chorób zakaźnych na potrzeby nadzoru epidemiologicznego") (4). W świetle powyższej definicji kryteria kliniczne spełnia każda osoba, u której występuje kaszel trwający co najmniej dwa tygodnie oraz co najmniej jeden $\mathrm{z}$ trzech objawów: napady kaszlu, napady bezdechu po kaszlu lub wymioty występujące bezpośrednio po kaszlu lub każda osoba, u której lekarz rozpoznał krztusiec lub napady bezdechu u niemowląt. Kryteria laboratoryjne obejmują, co najmniej jedno z trzech kryteriów: izolacja Bordetella pertussis z materiału klinicznego, wykrycie kwasu nukleinowego Bordetella pertussis w materiale klinicznym, wykrycie znamiennego wzrostu swoistych przeciwciał przeciw Bordetella pertussis. Kryteria epidemiologiczne są spełnione, gdy występuje powiązanie epidemiologiczne polegające na przeniesieniu zakażenia z człowieka na człowieka. Stosując kryteria kliniczne, laboratoryjne i epidemiologiczne ustalono następującą klasyfikację przypadku:

A. Przypadek możliwy - każda osoba spełniająca kryteria kliniczne

B. Przypadek prawdopodobny - każda osoba spełniająca kryteria kliniczne i epidemiologiczne

C. Przypadek potwierdzony - każda osoba spełniająca kryteria kliniczne i laboratoryjne.

\section{WYNIKI}

W 2016 r. zarejestrowano 6828 zachorowań na krztusiec tj. o $38 \%$ więcej niż w roku ubiegłym. Zapadalność w 2016 r. w Polsce wynosiła 17,77 na 100000 mieszkańców i w porównaniu z poprzednim rokiem $(12,9)$ była wyższa (Tab.I).

Table I. Pertusis in Poland in 2011-2016. Number of cases, incidence per 100000 and distribution of cases according to age

Tabela I. Krztusiec w Polsce w latach 2011-2016. Zachorowania i zapadalność na 100000 mieszkańców i udział procentowy zachorowań wg wieku

\begin{tabular}{|c|c|c|c|c|c|c|c|c|c|c|c|c|c|c|c|c|c|c|}
\hline \multirow{2}{*}{$\begin{array}{c}\text { Wiek } \\
\text { w latach }\end{array}$} & \multicolumn{3}{|c|}{2011} & \multicolumn{3}{|c|}{2012} & \multicolumn{3}{|c|}{2013} & \multicolumn{3}{|c|}{2014} & \multicolumn{3}{|c|}{2015} & \multicolumn{3}{|c|}{2016} \\
\hline & zach. & zapad. & $\%$ & zach. & zapad. & $\%$ & zach. & zapad. & $\%$ & zach. & zapad. & $\%$ & zach. & zapad. & $\%$ & zach. & zapad. & $\%$ \\
\hline 0 & 78 & 19.6 & 4.7 & 164 & 42.7 & 3.5 & 87 & 23.7 & 4.0 & 99 & 27.4 & 4.7 & 198 & 54.7 & 4.0 & 280 & 76.7 & 4.1 \\
\hline 1 & 35 & 8.3 & 2.1 & 92 & 22.7 & 2.0 & 56 & 14.3 & 2.6 & 55 & 14.5 & 2.6 & 130 & 35.0 & 2.6 & 200 & 53.7 & 2.9 \\
\hline 2 & 46 & 10.6 & 2.8 & 118 & 27.8 & 2.5 & 89 & 21.9 & 4.1 & 69 & 17.6 & 3.3 & 154 & 40.6 & 3.1 & 184 & 49.4 & 2.7 \\
\hline 3 & 87 & 20.8 & 5.2 & 173 & 39.9 & 3.7 & 148 & 34.9 & 6.8 & 134 & 33.0 & 6.4 & 219 & 55.7 & 4.4 & 292 & 77.0 & 4.3 \\
\hline 4 & 66 & 16.7 & 4.0 & 165 & 39.4 & 3.5 & 108 & 24.9 & 4.9 & 106 & 25.0 & 5.0 & 201 & 49.6 & 4.1 & 268 & 68.2 & 3.9 \\
\hline $0-4$ & 312 & 15.1 & 18.7 & 712 & 34.5 & 15.2 & 488 & 24.1 & 22.4 & 463 & 23.6 & 22.0 & 902 & 47.2 & 18.2 & 1224 & 65.0 & 17.9 \\
\hline $5-9$ & 134 & 7.4 & 8.0 & 358 & 19.4 & 7.6 & 254 & 13.3 & 11.6 & 270 & 13.6 & 12.9 & 554 & 27.1 & 11.2 & 883 & 42.6 & 12.9 \\
\hline $10-14$ & 397 & 20.3 & 23.8 & 1073 & 56.5 & 22.9 & 303 & 16.4 & 13.9 & 402 & 22 & 19.1 & 1191 & 66.1 & 24.0 & 1591 & 88.1 & 23.3 \\
\hline $15 \mathrm{i}>$ & 826 & 2.5 & 49.5 & 2541 & 7.8 & 54.2 & 1137 & 3.5 & 52.1 & 965 & 2.9 & 46.0 & 2308 & 7.1 & 46.6 & 3130 & 9.6 & 45.8 \\
\hline Ogółem & 1669 & 4.3 & 100.0 & 4684 & 12.2 & 100.0 & 2182 & 5.7 & 100.0 & 2100 & 5.5 & 100.0 & 4955 & 12.9 & 100.0 & 6828 & 17.8 & 100.0 \\
\hline
\end{tabular}


Agnieszka Rumik, Iwona Paradowska-Stankiewicz

Table II. Pertussis in Poland in 2016. Number of cases and incidence per 100000 population, according to voivodeship Tabela II. Krztusiec w Polsce w 2016 roku. Zachorowania i zapadalność na 100000 mieszkańców wg województw

\begin{tabular}{|l|c|c|c|c|}
\hline \multirow{2}{*}{ Voivodeship } & \multicolumn{2}{c|}{2015} & \multicolumn{2}{c|}{2016} \\
\cline { 2 - 5 } \multicolumn{1}{c|}{ Poland } & Number of cases & Incidence & Number of cases & 17.77 \\
\hline 1. Dolnośląskie & 4955 & 12.89 & 6828 & 12.47 \\
\hline 2. Kujawsko-Pomorskie & 149 & 5.13 & 362 & 26.82 \\
\hline 3. Lubelskie & 450 & 21.55 & 559 & 5.53 \\
\hline 4. Lubuskie & 100 & 4.67 & 71 & 6.98 \\
\hline 5. Lódzkie & 70 & 6.87 & 905 & 36.37 \\
\hline 6. Małopolskie & 675 & 27.02 & 911 & 26.98 \\
\hline 7. Mazowieckie & 481 & 14.27 & 884 & 16.50 \\
\hline 8. Opolskie & 1128 & 21.12 & 175 & 17.60 \\
\hline 9. Podkarpackie & 62 & 6.21 & 420 & 19.75 \\
\hline 10. Podlaskie & 88 & 4.14 & 482 & 40.59 \\
\hline 11. Pomorskie & 229 & 19.24 & 330 & 14.28 \\
\hline 12. Śląskie & 271 & 11.76 & 633 & 13.87 \\
\hline 13. Świętokrzyskie & 535 & 11.69 & 112 & 8.93 \\
\hline 14. Warmińsko-Mazurskie & 43 & 3.41 & 615 & 8.07 \\
\hline 15. Wielkopolskie & 45 & 3.12 & 135 & 17.68 \\
\hline 16. Zachodniopomorskie & 498 & 14.34 & 7.64 & 7.90 \\
\hline
\end{tabular}

In 2016, similarly to previous years, there is a large variation in incidence between voivodships. The highest number of cases, about $40 \%$ of all registered cases, occurred in the following voivodships: Małopolskie, Łódzkie and Mazowieckie (respectively: 911, 905 and 884 cases). The lowest number of cases was reported in the Lubuskie voivodeship: 71 cases. Such a large variation in incidence between individual regions may result from insufficient reporting of pertussis to the National Sanitary Inspection, which is also confirmed by the results of the National Epidemiology Study (BEKi), carried out at the Department of Epidemiology of NIPH-PZH.

In 2016, every third case of pertussis occurred in children aged 0 to 4 and from 5 to 9 years, the incidence in these groups was 65.0 and 42.6. Illnesses of children and adolescents aged 10-14 and persons over 15 years of age accounted for $69 \%$ of all cases (Tab. I). The highest percentage of cases, after approx. $23 \%$ and $33 \%$ of all cases, was found in age groups 10 14 years and over 20 years of age. In these age groups, the incidence per 100,000 persons was 88.1 and 7.3 respectively (Tab. III).

The total incidence of women in 2016, as in previous years, was higher in comparison with the incidence of men (respectively: 19.6 and 15.8). The above trend occurred in all age groups. Higher incidences were recorded in cities, in all age groups (Tab. III).

In about half of the group of patients with pertussis (3631 people) the course of the disease was defined as
W 2016 r. podobnie do lat ubiegłych stwierdza się duże zróżnicowanie zapadalności między województwami. Najwięcej zachorowań, około 40\% wszystkich zarejestrowanych przypadków, wystąpiło w województwach: małopolskim, łódzkim i mazowieckim (odpowiednio: 911, 905 i 884 zachorowań). Natomiast najniższą liczbę zachorowań zgłoszono w województwie lubuskim: 71 przypadków. Tak duże zróżnicowanie zapadalności między poszczególnymi województwami może wynikać z niedostatecznej zgłaszalności zachorowań na krztusiec do Państwowej Inspekcji Sanitarnej, co także potwierdzają wyniki Ogólnopolskiego Badania Epidemiologii Krztuśca (BEKi), realizowanego w Zakładzie Epidemiologii NIZP-PZH.

W 2016 r. co trzecie zachorowanie na krztusiec wystąpiło u dzieci w wieku od 0 do 4 i od 5 do 9 lat, zapadalność w tych grupach wynosiła 65,0 i 42,6. Zachorowania dzieci i młodzieży w wieku $10-14$ lat oraz osób powyżej 15 r.ż. stanowiły $69 \%$ ogółu przypadków (Tab. I). Najwyższy odsetek zachorowań, po ok. 23\% i 33\% ogółu przypadków, stwierdzono w grupach wieku 10-14 lat i powyżej 20 r.ż. W tych grupach wieku zapadalność na 100000 osób wynosiła odpowiednio 88,1 oraz 7,3 (Tab. III).

Zapadalność ogółem kobiet w 2016 r., podobnie jak w latach poprzednich, była wyższa w porównaniu z zapadalnością mężczyzn (odpowiednio: 19,6 i 15,8). Tendencja powyższa wystąpiła we wszystkich grupach wieku. Wyższą zapadalność zarejestrowano w miastach, we wszystkich grupach wieku (Tab. III). 
medium and in 88 severe. The severity of the course of the disease was not determined in $37 \%$ of people. Due to pertussis, 1640 people were hospitalized in 2016 .
U ok. połowy grupy osób chorych na krztusiec (3 631 osób ) przebieg choroby był określony, jako średni, a u 88 ciężki. Ciężkość przebiegu choroby nie została określona u $37 \%$ osób. Z powodu krztuśca hospitalizowano w 2016 r. 1640 osób.

Table III. Pertussis in Poland in 2016. Number of cases, incidence per 100000 and distribution of cases according to sex and age in urban and rural population

Tabela III. Krztusiec w Polsce w 2016 roku. Zachorowania i zapadalność na 100000 mieszkańców i udział procentowy zachorowań wg płci, wieku i środowiska

\begin{tabular}{|c|c|c|c|c|c|c|c|c|c|c|c|c|c|c|c|}
\hline \multirow{2}{*}{$\begin{array}{l}\text { Age } \\
\text { group }\end{array}$} & \multicolumn{3}{|c|}{ Men } & \multicolumn{3}{|c|}{ Women } & \multicolumn{3}{|c|}{ Urban } & \multicolumn{3}{|c|}{ Rural } & \multicolumn{3}{|c|}{ Total } \\
\hline & Cases & $\begin{array}{l}\text { Inci- } \\
\text { dence }\end{array}$ & $\%$ & Cases & $\begin{array}{l}\text { Inci- } \\
\text { dence }\end{array}$ & $\%$ & Cases & $\begin{array}{l}\text { Inci- } \\
\text { dence }\end{array}$ & $\%$ & Cases & $\begin{array}{l}\text { Inci- } \\
\text { dence }\end{array}$ & $\%$ & Cases & $\begin{array}{l}\text { Inci- } \\
\text { dence }\end{array}$ & $\%$ \\
\hline 0 & 139 & 74.1 & 4.7 & 141 & 79.4 & 3.6 & 156 & 72.6 & 3.6 & 124 & 82.6 & 5.0 & 280 & 76.7 & 4.1 \\
\hline 1 & 95 & 49.6 & 3.2 & 105 & 58.0 & 2.7 & 113 & 51.7 & 2.6 & 87 & 56.5 & 3.5 & 200 & 53.7 & 2.9 \\
\hline 2 & 87 & 45.5 & 3.0 & 97 & 53.6 & 2.5 & 116 & 53.5 & 2.7 & 68 & 43.7 & 2.8 & 184 & 49.4 & 2.7 \\
\hline 3 & 122 & 62.5 & 4.2 & 170 & 92.2 & 4.4 & 172 & 78.2 & 3.9 & 120 & 75.3 & 4.9 & 292 & 77.0 & 4.3 \\
\hline 4 & 128 & 63.3 & 4.4 & 140 & 73.4 & 3.6 & 162 & 71.3 & 3.7 & 106 & 64.1 & 4.3 & 268 & 68.2 & 3.9 \\
\hline $0-4$ & 571 & 59.0 & 19.5 & 653 & 71.4 & 16.8 & 719 & 65.5 & 16.5 & 505 & 64.4 & 20.5 & 1224 & 65.0 & 17.9 \\
\hline $5-9$ & 402 & 37.8 & 13.7 & 481 & 47.6 & 12.3 & 554 & 47.0 & 12.7 & 329 & 36.8 & 13.4 & 883 & 42.6 & 12.9 \\
\hline 10-14 & 742 & 80.1 & 25.3 & 849 & 96.6 & 21.8 & 1016 & 103.3 & 23.3 & 575 & 70.0 & 23.4 & 1591 & 88.1 & 23.3 \\
\hline $15-19$ & 409 & 41.0 & 13.9 & 485 & 51.0 & 12.5 & 557 & 53.1 & 12.8 & 337 & 37.5 & 13.7 & 894 & 45.9 & 13.1 \\
\hline $20 \mathrm{i}>$ & 809 & 5.5 & 27.6 & 1427 & 8.9 & 36.6 & 1520 & 8.1 & 34.8 & 716 & 6.0 & 29.1 & 2236 & 7.3 & 32.7 \\
\hline Total & 2933 & 15.8 & 100.0 & 3895 & 19.6 & 100.0 & 4366 & 18.9 & 100.0 & 2462 & 16.1 & 100.0 & 6828 & 17.8 & 100.0 \\
\hline
\end{tabular}

In 2016, 6165 pertussis laboratory diagnostics were carried out in 6165 patients: a serological test was carried out in 6102 , a PCR test - in 61 patients, and in 2 cases bacteriological confirmation was obtained by isolation of pertussis rods. Pertussis was diagnosed on the basis of clinical symptoms in 663 patients. In 2016, no death was reported due to pertussis.

In 2016, they were qualified using the current case definitions - $3884(57 \%)$ of possible cases, $192(3 \%)$ probable and 2752 (40\%) confirmed.

Vaccinations against pertussis in 2016. In 2016, the level of inoculation of children in the 2 year of age against pertussis it remained at a high level from $96.1 \%$ to $99.4 \%$ on a national scale. The analysis of epidemiological reports shows that in the group of 6828 people who contracted pertussis in 2016, 644 people were not vaccinated, because they were born before the introduction of vaccination (born before 1960) or because of the age below 2 months (not included in the vaccination calendar) or received periodic / permanent release from vaccinations $(9 \%$ unvaccinated). About 1628 patients are not known if they were vaccinated. However, among the remaining patients, 1608 people received primary vaccination (4 doses), and 2482 people received supplementary vaccination (5 doses). The remaining 283 people received 3 doses of vaccination, 50 people - 2 doses, 103 people - 1 dose.
W 2016 r. u 6165 chorych przeprowadzono diagnostykę laboratoryjną krztuśca: badanie serologiczne wykonano u 6 102, badanie PCR - u 61 osób, a w 2 przypadkach uzyskano potwierdzenie bakteriologiczne izolacją pałeczek krztuśca. Krztusiec rozpoznano na podstawie objawów klinicznych u 663 chorych. W 2016 r. z powodu krztuśca nie zgłoszono żadnego zgonu.

W 2016 r. zakwalifikowano stosując obowiązujące definicje przypadku - 3884 (57\%) przypadków możliwych, 192 (3\%) prawdopodobnych oraz $2752(40 \%)$ potwierdzonych.

Szczepienia przeciw krztuścowi w 2016 r. W 2016 r. poziom zaszczepienia dzieci w 2 r.ż. przeciw krztuścowi utrzymywał się na wysokim poziomie od $96,1 \%$ do $99,4 \%$ w skali kraju. Z analizy meldunków epidemiologicznych wynika, że w grupie 6828 osób, które w 2016 r. zachorowały na krztusiec, 644 osoby nie były zaszczepione, ponieważ urodziły się jeszcze przed wprowadzeniem szczepień (urodzone przed 1960 r.) lub ze względu na wiek poniżej $2 \mathrm{~m} . \dot{\text {. }}$. (nie były objęte kalendarzem szczepień) lub otrzymały okresowe/trwałe zwolnienie ze szczepień $(9 \%$ nieszczepionych). O 1628 chorych nie wiadomo, czy były szczepione. Natomiast wśród pozostałych chorych 1608 osób otrzymało szczepienie podstawowe (4 dawki), a 2482 osoby szczepienie uzupełniające (5 dawek). Pozostałe 283 osoby otrzymały 3 dawki szczepienia, 50 osób - 2 dawki, 103 osoby - 1 dawkę. 
According to the Protective Vaccination Program, every child should receive 4 doses of DTPw vaccine in: 2,3-4, 5-6 and 16-18 months of life (primary vaccination with a full-cell pertussis vaccine) and a booster dose of acellular vaccine (DTPa) in 6 years life. Due to the more and more frequent cases of pertussis of young people and adults, from 2016 compulsory vaccinations (dTap vaccine - with reduced content of diphtheria and pertussis antigens) were applied to adolescents in the of aged 14 (booster dose). The decision to vaccinate young people against pertussis with a booster dose was already introduced in 2004 by some western countries (including France) (5). In addition, vaccinations against pertussis (dTap) are recommended for women planning pregnancy or pregnancy (after the 28th week of pregnancy). The conducted research has shown that one of the most effective strategies to reduce pertussis disease among infants is vaccination of mothers with Tdap vaccine $(6,7)$. Vaccines against pertussis used in Poland are associated with the diphtheria and tetanus vaccine (DTPw / DTPa / dTap). In the country, also available are acellular vaccines (DTPa) additionally combined with Hib vaccine, inactivated polio vaccine and hepatitis $B$ vaccine. The reasons for the increase in pertussis in some countries include, among others, the introduction of acellular vaccines, after which the duration of immunity is rapidly disappearing than in the case of whole-cell vaccines (8). The development of new vaccines (inducing long-term protection and having an acceptable number of side effects) is currently the goal of many studies $(9,10)$.

\section{SUMMARY AND CONCLUSIONS}

The year 2016 with higher than in the previous year can be treated as another year of the pertussis epidemic severity, which confirms the occurrence of cyclical increases in pertussis disease. The best strategy for the prevention of pertussis is the use of vaccinations in age groups with increasing risk of disease - in the current epidemiological situation for infants, teenage adolescents and the elderly. In the above-mentioned groups and specific occupational groups, such as neonatal, infant, teacher, elderly people caring for young children, booster vaccinations containing a pertussis-acellular component should be repeated every 10 years.

\section{REFERENCES}

1. Paradowska-Stankiewicz I, Rudowska J. Pertussis in Poland in 2015. Przegl Epidemiol 2017; 71(4):481-485.

2. Czarkowski M P, et al. Choroby zakaźne i zatrucia w Polsce w 2016 r. Warszawa: NIZP-PZH; GIS, 2017, www. pzh.gov.pl
Według Programu Szczepień Ochronnych każde dziecko powinno otrzymać 4 dawki szczepionki DTP w: 2, 3-4, 5-6 i 16-18 miesiącach życia (szczepienie podstawowe przy użyciu pełnokomórkowej szczepionki przeciw krztuścowi) oraz dawkę przypominającą szczepionką acelularną (DTPa) w 6 roku życia. $\mathrm{Z}$ powodu coraz częstszych zachorowań na krztusiec osób młodych i dorosłych, od 2016 r. objęto obowiązkowymi szczepieniami (szczepionką dTap - o obniżonej zawartości antygenów błonicy i krztuśca) młodzież w 14 r.ż. (dawka przypominająca). Decyzję szczepienia młodzieży przeciw krztuścowi dawką przypominającą wprowadziły już w 2004 r. niektóre kraje zachodnie (m.in. Francja) (5). Ponadto zalecono szczepienia przeciwko krztuścowi (dTap) kobietom planującym ciążę lub w ciąży (po 28. tygodniu ciąży). Przeprowadzone badania wykazały, że jedną z najskuteczniejszych strategii ograniczenia zachorowań na krztusiec wśród niemowląt, jest szczepienie matek szczepionką Tdap $(6,7)$. Szczepionki przeciw krztuścowi stosowane w Polsce są skojarzone ze szczepionką przeciw błonicy i przeciw tężcowi (DTPw/DTPa/ dTap). W kraju dostępne są także szczepionki acelularne (DTPa) skojarzone ze szczepionkami przeciw Hib, inaktywowaną szczepionką przeciw poliomyelitis oraz szczepionką przeciw wzw typu B. Do przyczyn wzrostu zachorowalności na krztusiec w niektórych krajach zalicza się $\mathrm{m}$. in. wprowadzenie szczepionek acelularnych, po których czas utrzymywania się odporności na zachorowanie szybciej zanika, niż w przypadku szczepionek pełnokomórkowych (8). Opracowanie nowych szczepionek (indukujących długi czas trwania ochrony oraz mających dopuszczalną liczbę działań niepożądanych) jest obecnie celem wielu badań $(9,10)$.

\section{PODSUMOWANIE I WNIOSKI}

Rok 2016 o wyższej w porównaniu do poprzedniego roku zapadalności można traktować jako kolejny rok nasilenia epidemicznego krztuśca, co potwierdza występowanie cyklicznych wzrostów zachorowań na krztusiec. Najlepszą strategią profilaktyki krztuśca jest stosowanie szczepień w grupach wieku o narastającym ryzyku zachorowania - w obecnej sytuacji epidemiologicznej niemowlętom, młodzieży nastoletniej oraz osobom starszym. W wymienionych grupach oraz określonych grupach zawodowych, takich jak personel oddziałów noworodkowych, niemowlęcych, nauczyciele, osoby starsze opiekujące się małymi dziećmi, szczepienia przypominające szczepionką zawierającą komponent krztuścowy bezkomórkowy należy powtarzać, co 10 lat. 
3. Czarkowski M P, et al. Szczepienia ochronne w Polsce w 2016 r. Warszawa: NIZP-PZH; GIS, 2017, www. pzh.gov.pl

4. Definicje przypadków chorób zakaźnych na potrzeby nadzoru epidemiologicznego stosowane w latach 2014-2016. Zakład Epidemiologii NIZP-PZH, www. pzh.gov.pl

5. A. Lutyńska, A. Wiatrzyk, E. Mosiej, M. Zawadka. Szczepienia młodzieży i osób dorosłych jako strategia poprawy sytuacji epidemiologicznej zachorowań na krztusiec. Przegl Epidemiol 2011, 65(1): 45-50

6. Becker-Dreps, Butler, McGrath, Boggess, Weber, Li, Hudgens, Layton. Effectiveness of Prenatal Tetanus, Diphtheria, Acellular Pertussis Vaccination in the Prevention of Infant Pertussis in the U.S. Am J Prev Med 2018 Aug;55(2):159-166.

7. Forsyth, Plotkin, Tan, Wirsing von König. Strategies to decrease pertussis transmission to infants. Pediatrics 2015 Jun;135(6):e1475-82.

8. Burdin, Handy, Plotkin. What Is Wrong with Pertussis Vaccine Immunity? The Problem of Waning Effectiveness of Pertussis Vaccines. Cold Spring
Harb Perspect Biol. 2017 Dec 1;9(12).

9. Saadatian-Elahi, Plotkin, Mills, Halperin, McIntyre, Picot, Louis, Johnson. Pertussis: Biology, epidemiology and prevention. Vaccine 2016 Nov 21;34(48):5819-5826.

10. Plotkin. Increasing Complexity of Vaccine Development. J Infect Dis 2015 Jul 15;212 Suppl 1:S12-6.

Received: 3.08.2018

Accepted for publications: 5.09.2018

Otrzymano: 3.08.2018 r.

Zaakceptowano do publikacji: 5.09. 2018r.

\section{Address for correspondence: \\ Adres do korespondencji:}

Dr n. med. Iwona Paradowska-Stankiewicz

Zakład Epidemiologii Chorób Zakaźnych i Nadzoru

Narodowy Instytut Zdrowia Publicznego

-Państwowy Zakład Higieny

Ul. Chocimska 24, 00-791 Warszawa

tel. +48225421372

e-mail: istankiewicz@pzh.gov.pl 